\title{
Metal Concentrations of Red Wines in Southeast Romania
}

\author{
Florin Dumitru BORA ${ }^{1}$, Alina DONICI ${ }^{1}$, Elena POSTOLACHE ${ }^{1}$, Aurel CIUBUCA $\breve{A}^{1}$, \\ Viorica ENACHE ${ }^{1}$, Gabriel TABARANU ${ }^{1}$, Nicolaie BÎRLIGA ${ }^{1}$, Ionut RACZ ${ }^{2}$, \\ Claudiu Ioan BUNEA ${ }^{3 *}$
}

${ }^{1}$ Department of Physico-Chemistry and Biochemistry, Research Station for Viticulture and Enology Târgu Bujoru, Romania.

${ }^{2}$ Wheat Breeding Department, Agricultural Research and Development Station Turda, Cluj-Napoca, Romania.

${ }^{3}$ Department of Horticulture and Landscaping, University of Agricultural Sciences and Veterinary Medicine, Cluj-Napoca, Romania.

*Corresponding author, e-mail: claus_bunea@yahoo.com

Bulletin UASVM Horticulture 74(2)/ 2017

Print ISSN 1843-5254, Electronic ISSN 1843-5394

DOI:10.15835/buasvmcn-hort: 0004

\begin{abstract}
Daily consumption, wine contributes to the requirements of essential elements, such as Ca, Fe, Mn, Mo, Co, $\mathrm{Cr}, \mathrm{K}, \mathrm{Ni}$, Se and $\mathrm{Zn}$ for humans. However, the presence of significant amount of heavy metal in wine may harm the health of consumers. The present work is aimed at establishing the heavy metal content in red wines from Dealu Bujorului vineyard using ICP-MS method for the determination of metals content. In this study 3 red wines obtained from 'Băbească neagră, 'Negru Aromat' and 'Burgund Mare' cultivars were investigated. The wine samples were obtained from micro-wine production under conditions of 2014, 2015, 2016 from Dealu Bujorului vineyard. The determination of 13 elements was performed with ICP-MS. The high level of Ca (64.81-62.49 mg/L), Mg (132.61$101.44 \mathrm{mg} / \mathrm{L}$ ) and Fe were observed in the wine samples analysed. Heavy metals like As, $\mathrm{Cd}, \mathrm{U}, \mathrm{Hg}$ and $\mathrm{Pb}$ was found below acceptable limits. Concentration of $\mathrm{Na}(1 \mathrm{mg} / \mathrm{L}), \mathrm{Cu}(1 \mathrm{mg} / \mathrm{L}), \mathrm{As}(0.2 \mathrm{mg} / \mathrm{L}), \mathrm{Cd}(0.01 \mathrm{mg} / \mathrm{L}), \mathrm{Zn}(5$ $\mathrm{mg} / \mathrm{L})$ and $\mathrm{Pb}(0.15 \mathrm{mg} / \mathrm{L})$ metals in analysed wine samples were under Maximum Permissible Limits (MPL), respectively as published by the Organization of Vine and Wine. Calcium and magnesium were the most abundant elements in all investigated wine samples. Concentration of $\mathrm{Na}(1 \mathrm{mg} / \mathrm{L}), \mathrm{Cu}(1 \mathrm{mg} / \mathrm{L}), \mathrm{As}(0.2 \mathrm{mg} / \mathrm{L}), \mathrm{Cd}(0.01$ $\mathrm{mg} / \mathrm{L}), \mathrm{Zn}(5 \mathrm{mg} / \mathrm{L})$ and $\mathrm{Pb}(0.15 \mathrm{mg} / \mathrm{L})$ in analysed wine samples were under Maximum Permissible Limits (MPL), respectively as published by the Organization of Vine and Wine.
\end{abstract}

Keywords: mineral content, ICP-MS, Vitis vinifera

\section{INTRODUCTION}

Many metals are among the hundreds of different substances commonly found in wines. Only one sample of wine (Australian Shiraz) detected 30 metals with a total concentration of more than $5600 \mathrm{mg} / \mathrm{L}$ (Hague et al., 2008). Metals enter a wine as a final product in different ways, while their structure and concentration in wine depend on at least four sources. The first, and frequently mentioned source, involves soil on which a vineyard area is established, and capacity of wine to absorb various mineral sustances (Blesić et al., 2017). The second source is linked to the ways and conditions of grape production, among which applications of pesticides and environmental air pollution are frequently stressed (Angelova et al., 1999). The third source of factors are those related to the alcoholic fermentation and possibly added different substances (oenological substances) during the production of wine (Catarino et al., 2008). The fourth source includes subsequent contaminations of wine with metals by the 
Tab. 1. Ecoclimatic conditions in Dealu Bujorului Vineyard

\begin{tabular}{ccccccc}
\hline & \multicolumn{2}{c}{$\begin{array}{c}\text { Annual } \\
\text { period }\end{array}$} & \multicolumn{2}{c}{ Conventional vegetation period } & \\
\cline { 2 - 6 } Period & $\begin{array}{c}\text { Average } \\
\text { temperature } \\
\left({ }^{\circ} \mathrm{C}\right)\end{array}$ & $\begin{array}{c}\text { Average } \\
\text { precipitation } \\
(\mathrm{mm})\end{array}$ & $\begin{array}{c}\text { Average } \\
\text { temperature } \\
\left({ }^{\circ} \mathrm{C}\right)\end{array}$ & $\begin{array}{c}\text { Insolation } \\
\text { (hours) }\end{array}$ & $\begin{array}{c}\text { Average } \\
\text { precipitation } \\
(\mathrm{mm})\end{array}$ & $\begin{array}{c}\text { Ondex } \\
\text { index }\end{array}$ \\
\hline $2003-2013$ & 11.7 & 470.6 & 3536.6 & 1392.7 & 295.6 & 4883.6 \\
\hline 2014 & 10.8 & 450.2 & 3220.3 & 1337.0 & 258.0 & 4549.3 \\
\hline 2015 & 11.4 & 525.4 & 3358.6 & 1480.5 & 218.2 & 4870.9 \\
\hline 2016 & 11.2 & 690.4 & 3369.8 & 1449.5 & 319.4 & 4749.9 \\
\hline
\end{tabular}

equipment used during the wine making process, the characteristics of vessels for wine storage, and also the characteristics of a glass used for wine bottles (Kristl et al., 2003).

Metals in wines may have a number of roles, organoleptic characteristics can be influenced positively or negatively, through causes of theier different instabilities, to the fact that wines can be considered sources of metals needed in human diet (Blesić et al., 2017). Besides the metals which are typically abundant in grapes $(\mathrm{Ca}, \mathrm{Mg}$ and $\mathrm{K}$ ), metals such as $\mathrm{Cu}, \mathrm{Fe}, \mathrm{Cr}, \mathrm{Zn}$ and $\mathrm{Mn}$ are necessary or useful in a series of physiological processes in wine yeasts and humas (Marais and Blakhurst, 2009). The high concentration of metals in wines, as well as in other food may jeopardize the consumers health. The fact is that so far there have not been precise characterization of the impact of a number of metals found in food on human health. Only $\mathrm{Pb}, \mathrm{Hg}$ and $\mathrm{Cd}$ are undoubtedly considered toxic, with a certain possibility of toxicity for $\mathrm{Ni}, \mathrm{Cu}, \mathrm{V}, \mathrm{Cr}, \mathrm{Al}$ and $\mathrm{Ag}$ in high concentrations (Marais and Blakhurst, 2009). Consequently, the Organisation International de la Vigne et du Vin (OIV) established maximum acceptable limits for only a few elements in wine $(\mathrm{Pb}, \mathrm{Cd}, \mathrm{Cu}, \mathrm{Zn}$, $\mathrm{Na}, \mathrm{Ag}, \mathrm{As}, \mathrm{Br}, \mathrm{F}$ and $\mathrm{B}$; OIV International Code of Oenological Practices, 2015).

The aim of this study was to find concentration of the challenged thirteen metals $(\mathrm{Ca}, \mathrm{Mg}, \mathrm{Na}, \mathrm{Cu}$, $\mathrm{Fe}, \mathrm{As}, \mathrm{Cd}, \mathrm{Cr}, \mathrm{Ni}, \mathrm{U}, \mathrm{Zn}, \mathrm{Hg}$ and $\mathrm{Pb}$ ) in red wine from the vintage 2014, 2015 and 2016 originating from the Dealu Bujorului vineyard.

\section{MATERIALS AND METHODS Study area}

A total of 21 wine samples were analysed (9 red wines). Samples originated from Dealu
Bujorului vineyard $\left(45^{\circ} 52^{\prime} 10^{\prime \prime} \mathrm{N}, 27^{\circ} 55^{\prime} 8^{\prime \prime} \mathrm{E}\right)$ ( $\mathrm{n}=$ 21). The Dealu Bujorului vineyard is characterized by an alternate landscape, from flat to hilly areas, with altitude between 100 and $225 \mathrm{~m}$ and the predominant soil is levigated chernozem having a clayey sand texture with $\mathrm{pH}$ between values 7.4 and 8.1. Although they have moisture deficit, natural conditions (ecoclimatic and ecopedological) offer viable ecosystem for the development of vineyard. Centers of vineyard are: Bujoru, Smulti, Oancea, Beresti.

The 2014-2016 period showed a therMPL deficit compared with the average 2003-2013, the maximum deficit of $0.9 \stackrel{\circ}{\circ} \mathrm{C}$ was recorded in 2014. Precipitation varied from $450.2 \mathrm{~mm} / 2014$ to $690.4 \mathrm{~mm} / 2016$. During the vegetation period the optiMPL precipitation $(250 \mathrm{~mm})$ was recorded in 2014 and 2016, in 2015 the precipitation decreases $(31.8 \mathrm{~mm})$ compared with the optiMPL precipitation. The isolation from vegetation period ranges from 1337.0 hours/2014 to 1480.5 hours/2015. The values of the oenological index in 2014 shows that in this vineyard had presented more favorable conditions for red wine and in 2015-2016 values of the oenological index shows there are more favorable conditions for white wines.

\section{Sample collection and microvinification} process

The samples used in this experiment were obtained from the wines produced from 'Băbească Neagră', 'Negru Aromat', and 'Burgund Mare' under the conditions of 2014, 2015 and 2016 year, from Dealu Bujorului vineyard. The wine samples resulted from micro-wine production. Micro-vine production it was done according to the methodology described by Bora et al. (2016). All wines were providing by the wineries as finished wines in $750 \mathrm{~mL}$ glass bottles with cork 
Tab. 2. Instrumental conditions for the determination of each element (ICP-MS technique)

\begin{tabular}{cccccccccc}
\hline Element & $\begin{array}{c}\text { Correlation } \\
\text { coefficient }\end{array}$ & $\begin{array}{c}\text { LoD* } \\
(\mu \mathrm{g} / \mathrm{L})\end{array}$ & $\begin{array}{c}\text { LoQ*** } \\
(\mu \mathrm{g} / \mathrm{L})\end{array}$ & $\begin{array}{c}\text { BEC** } \\
(\mu \mathrm{g} / \mathrm{L})\end{array}$ & Element $\begin{array}{c}\text { Correlation } \\
\text { coefficient }\end{array}$ & $\begin{array}{c}\text { LoD* } \\
(\mu \mathrm{g} / \mathrm{L})\end{array}$ & $\begin{array}{c}\text { LoQ*** } \\
(\mu \mathrm{g} / \mathrm{L})\end{array}$ & $\begin{array}{c}\text { BEC** } \\
(\mu \mathrm{g} / \mathrm{L})\end{array}$ \\
\hline $\mathrm{Ca}$ & 0.9999 & 5.66 & 18.86 & 20.82 & $\mathrm{Mg}$ & 0.9999 & 2.73 & 9.09 & 9.09 \\
\hline $\mathrm{Na}$ & 0.9999 & 3.98 & 13.25 & 32.12 & $\mathrm{Cu}$ & 0.9999 & 0.04 & 0.13 & 0.23 \\
\hline $\mathrm{Fe}$ & 0.9999 & 5.21 & 17.35 & 71.39 & $\mathrm{As}$ & 0.9999 & 0.23 & 0.77 & 0.53 \\
\hline $\mathrm{Cd}$ & 0.9999 & 0.02 & 0.06 & 0.02 & $\mathrm{Cr}$ & 0.9999 & 1.66 & 5.53 & 0.63 \\
\hline $\mathrm{Ni}$ & 0.9999 & 0.05 & 0.19 & 0.09 & $\mathrm{U}$ & 0.9999 & 0.02 & 0.08 & 0.00 \\
\hline $\mathrm{Zn}$ & 0.9999 & 0.37 & 1.25 & 5.40 & $\mathrm{Hg}$ & 0.9999 & 0.04 & 0.13 & 0.12 \\
\hline $\mathrm{Pb}$ & 0.9999 & 0.003 & 0.001 & 0.002 & & & & &
\end{tabular}

stoppers and were stored at $3-4^{\circ} \mathrm{C}$ before analysis. One bottle was used for each sample, and three replicates were taken. All vines were planted since 1979 , and the vine plantation was organized with $2.2 \times 1 \mathrm{~m}$ distance between rows and plants. Vines were pruned according to the Guyot system and were grown on speliers.

\section{Reagents and solutions}

Thirteen elements ( $\mathrm{Ca}, \mathrm{Mg}, \mathrm{Na}, \mathrm{Cu}, \mathrm{Fe}, \mathrm{As}, \mathrm{Cd}$, $\mathrm{Cr}, \mathrm{Ni}, \mathrm{U}, \mathrm{Zn}, \mathrm{Hg}$ and $\mathrm{Pb}$ ) were determined in order to assess their concentration in wines samples. The analysis was made using multielement analysis and ICP-MS technique, after an appropriate dilution, using external standard calibration method. Each sample was analyzed in duplicate and each analysis was prepared from consisted of three replicates. The calibration was performed using XXI CertiPUR multielement standard solution and from individual standard solution of $\mathrm{Hg}$. The intermediate solutions stored in polyethylene bottles and glassware were cleaned by soaking in $10 \% \mathrm{v} / \mathrm{v} \mathrm{HNO}_{3}$ for 24 hours and rinsing at least ten times with ultrapure water (Milli-Q Integral ultrapure water-Type 1). The accuracy of the methods was evaluated by replicate analyses of fortified samples (10 $\mu \mathrm{L}-10 \mathrm{~mL}$ concentrations) and the obtained values ranged between 0.8$13.1 \%$, depending on the element. The global recovery for each element was estimated and the obtained values were between 84.6-100.9\%.

For quality control purpose, blanks and triplicates samples $(n=3)$ were analyzed during the procedure. The variation coefficient was under $5 \%$ and detection limits ( $\mathrm{ppb}$ ) were determined by the calibration curve method. Limit of detection (LoD) and Limit of quantification (LoQ) limits were calculated according to the next mathematical formulas: $\mathrm{LoD}=3 \mathrm{SD} / \mathrm{s}$ and $\mathrm{LoQ}=10 \mathrm{SD} / \mathrm{s}(\mathrm{SD}$
= estimation of the standard deviation of the regression line; $\mathrm{s}=$ slope of the calibration curve).

Sample preparation for determination of metals from wine using ICP-MS.

For the determination of metals from wine samples were used an amount of $0.2 \mathrm{~mL}$ wine and adjust $8 \mathrm{~mL} \mathrm{(7} \mathrm{mL} \mathrm{HNO}_{3} 69 \%+1 \mathrm{~mL} \mathrm{H}_{2} \mathrm{O}_{2}$ ), after 15-30 minutes the mineralization was performed using a microwave system Milestone START D Microwave Digestion System set in three steps: step I (time $10 \mathrm{~min}$., temperature $200^{\circ} \mathrm{C}$ ), step II (time $15 \mathrm{~min}$. , temperature $200^{\circ} \mathrm{C}$ ) and step III (time $60 \mathrm{~min}$., ventilation - temperature $35^{\circ} \mathrm{C}$ ). After mineralization, samples were filtered through a $0.45 \mathrm{~mm}$ filter and brought to a volume of $50 \mathrm{~mL}$.

\section{Instrumentation}

The determination of metals was performed on mass spectrometer with inductively coupled plasma, iCAP Q Thermo scientific model (ICP-MS), based polyatomic species before they reach the quadrupole mass spectrometer. The instrument was daily optimized to give maximum sensitivity for $\mathrm{M}^{+}$ions and the double ionization and oxides monitored by the means of the ratio between $\mathrm{Ba}^{2+}$ / $\mathrm{Ba}^{+}$and $\mathrm{Ce}^{2+} / \mathrm{CeO}^{+}$, respectively, these always being less than $2 \%$. The experimental conditions were: argon flow on nebulizer $(0.84 \mathrm{~L} / \mathrm{min}$.), auxiliary gas flow $0.80 \mathrm{~L} / \mathrm{min}$., argon flow in plasma $15 \mathrm{~L} /$ min., lens voltage $7.31 \mathrm{~V}$; RF power in plasma 1100 $\mathrm{W}$, spray chamber temperature $\left(2.51 \pm 1.00{ }^{\circ} \mathrm{C}\right)$. Accuracy was calculated for the elements taken into consideration (0.5-5.0\%).

\section{Statistical analysis}

The statistical interpretation of the results was performed using the Duncan test, SPSS Version 24 (SPSS Inc., Chicago, IL., USA). The statistical processing of the results was primarily performed 
in order to calculate the following statistical parameters: average and standard deviation. This data was interpreted with the analysis of variance (ANOVA) and the average separation was performed with the DUNCAN test at $p \leq 0.05$. In order to determine if the concentration of metals can influence each other, the correlation coefficient was calculated using SPSS version 23 Pearson (SPSS Inc., Chicago, IL., USA).

\section{RESULTS AND DISCUSSION}

Tables 2-3 give the elemental concentration of the wines for Center Târgu Bujoru, Dealu Bujorului vineyard. For some samples the elemental concentration were not significantly above limit of detection (LOD) and therefore the LOD appers as a lower limit of the range for that particular region. In such cases these samples were not included in the calculations of the mean and standard deviation (sd).

In Table 3 we present the content of major elements in wine samples. $\mathrm{Mg}$ and $\mathrm{Ca}$ show high concentrations in wine. $\mathrm{Mg}$ is an essential micronutrient in plants bening an essential elements in the chlorophyll molecule and, together with calcium contributes to the structure of the cell walls (dos Santos et al., 2010). Mg concentration is quite stable in the analysed wines. In most samples, the concentration varied in the range of $101.44 \pm 1.92-132.61 \pm 2.43 \mathrm{mg} / \mathrm{L}$ with an average of $113.04 \pm 4.55 \mathrm{mg} / \mathrm{L}$. Ca is a natural constituent of grapes, although this, may be influenced by the addition of fungicides used for spraying of vines may also contribute to the Ca content of wine (Álvarez et al., 2007). The concentration of Ca varied in the range of 51.36 $\pm 2.26-64.81 \pm 3.36$ $\mathrm{mg} / \mathrm{L}$ with an average of $58.38 \pm 2.67 \mathrm{mg} / \mathrm{L}$. Variety 'Burgund Mare' (2014) and 'Băbească Neagră' (2014) has recorded the highest concentration of $\mathrm{Mg}$ and Ca while the lowest values were recorded to 'Băbească Neagră' (2014) and 'Burgund Mare' (2016) variety. Just in the case of $\mathrm{Mg}$, $\mathrm{Na}$ is stable in the analysed wines. 'Negru Aromat' variety was recorded the higest values [53.49 $\pm 5.04 \mathrm{mg} / \mathrm{L}$ (2015)] and also de loweste values [40.20 \pm 1.96 mg/L (2014)] of Na (Tab. 3).

Regarding $\mathrm{Fe}$ concentration in wines, this varied in the range of $1.66 \pm 0.18-2.35 \pm 0.17 \mathrm{mg} / \mathrm{L}$ with an average of $1.96 \pm 0.11 \mathrm{mg} / \mathrm{L}$. Varietis 'Negru Aromat'[2.35 $\pm 0.17 \mathrm{mg} / \mathrm{L}$ (2015); $2.35 \pm 0.14 \mathrm{mg} / \mathrm{L}$
(2014)] and 'Băbească Neagră' [2.19 0.15 mg/L (2015)] recorded the higest values.

It is well-known that $\mathrm{Cu}$ is one of the most studied element in wine-growing areas. It is effective against a high number of crop pests and it is utilised as a fungicide, a bactericide and also as a herbicide (Provenzano et al., 2010). Different $\mathrm{Cu}$ formulations are used against grapevine (Vitis vinifera L.) downy mildew and they have a secondary effect on grapevine powdery mildew and on a wide range of other grapevine insect pests and diseases (Boubals et al., 2001). The average value of $\mathrm{Cu}$ in wines samples were $0.64 \mathrm{mg} / \mathrm{L}$, with a minimum of $0.50 \mathrm{mg} / \mathrm{L}$ and a maximum of $0.75 \mathrm{mg} / \mathrm{L}$. Varietis 'Negru Aromat' [0.75 $\pm 0.11 \mathrm{mg} / \mathrm{L}$ (2014); 0.71 $\pm 0.03 \mathrm{mg} / \mathrm{L}$ (2015)] recorded the higest values while 'Burgund Mare' variety recorded de lowest values $[0.50 \pm 0.02$ $\mathrm{mg} / \mathrm{L}$ (2014)].

Concentration of $\mathrm{Na}(60 \mathrm{mg} / \mathrm{L})$ and $\mathrm{Cu}(1$ $\mathrm{mg} / \mathrm{L}$ ) metals in analysed wine samples were under Maximum Permissible Limits (MPL), respectively as published by the Organization of Vine and Wine (OIV 2016).

Regarding the content of As, Cd and Cr (Tab. 4), the $\mathrm{Cr}$ was recorded the higest values, followed by $\mathrm{Cd}$ and As. Concentration of $\mathrm{Cr}$ from wines varied in the range of $331.19 \pm 2.20$ to $672.42 \pm 2.93$ $\mu \mathrm{g} / \mathrm{L}$ with an average of $489.15 \pm 5.15 \mu \mathrm{g} / \mathrm{L}$ compared with As concentration $(10.09 \pm 0.51$ $\mu \mathrm{g} / \mathrm{L}$ to $14.79 \pm 3.28$ with an average of $11.66 \pm 1.07$ $\mu \mathrm{g} / \mathrm{L})$ and $\mathrm{Cd}(0.11 \pm 0.03 \mu \mathrm{g} / \mathrm{L}$ to $0.17 \pm 0.02$ with an average of $0.13 \pm 0.02 \mu \mathrm{g} / \mathrm{L}$ ). 'Băbească Neagră' variety recorded the lowest concentration of $\mathrm{Cd}$ $[0.11 \pm 0.03 \mu \mathrm{g} / \mathrm{L}(2016)]$ and $\mathrm{Cr}$ [331.19 \pm 2.20 $\mu \mathrm{g} / \mathrm{L}$ (2015)], in case of As 'Burgund Mare' variety recorded the lowest concentration As $[10.09 \pm 0.51$ $\mu \mathrm{g} / \mathrm{L}$ (2014)]. The highest concentration of As and $\mathrm{Cr}$ was recorded in wine obtained from 'Burgund Mare' variety [14.79 $\pm 3.28 \mu \mathrm{g} / \mathrm{L}$ As (2016)] and

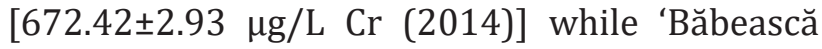
Neagră' variety recorded the highest concentration of Cd [0.17 $\pm 0.02 \mu \mathrm{g} / \mathrm{L}(2014)]$.

Concentration of $\mathrm{Ni}$ from wines varied in the range of $528.87 \pm 6.51$ to $722.07 \pm 6.21 \mu \mathrm{g} / \mathrm{L}$ with an average of $616.00 \pm 4.98 \mu \mathrm{g} / \mathrm{L}$. It can be seen as the 'Băbească Neagră' variety were recorded the lowest concentration $[528.87 \pm 6.51 \mu \mathrm{g} / \mathrm{L} \mathrm{Ni}$ (2015)] and at the opposite pole with the highest concentration was recorden in the 'Cabernet Sauvignon' variety [722.07 $\pm 6.21 \mu \mathrm{g} / \mathrm{L} \mathrm{Ni}$ (2014)]. 
Tab. 3. The content of major element in wine samples (mg/L) (Mean \pm standard deviation) $(n=3)$

\begin{tabular}{|c|c|c|c|c|c|c|c|}
\hline \multirow{4}{*}{ 思 } & \multirow{4}{*}{ Variety } & \multirow{4}{*}{ Years } & \multicolumn{5}{|c|}{ Total metal concentration } \\
\hline & & & $\mathrm{Ca}(\mathrm{mg} / \mathrm{L})$ & $\mathrm{Mg}(\mathrm{mg} / \mathrm{L})$ & $\mathrm{Na}(\mathrm{mg} / \mathrm{L})$ & $\mathrm{Cu}(\mathrm{mg} / \mathrm{L})$ & $\mathrm{Fe}(\mathrm{mg} / \mathrm{L})$ \\
\hline & & & M.P.L. & M.P.L. & M.P.L. & M.P.L. & M.P.L. \\
\hline & & & - & - & $60 \mathrm{mg} / \mathrm{L}$ & $1 \mathrm{mg} / \mathrm{L}$ & - \\
\hline \multirow{9}{*}{ 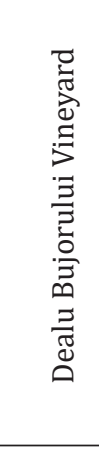 } & \multirow{3}{*}{$\begin{array}{l}\text { 'Băbească } \\
\text { Neagră' }\end{array}$} & 2014 & $51.36 \pm 2.26 \mathrm{~b} \beta$ & $132.61 \pm 2.43$ a $\alpha$ & $44.55 \pm 1.19$ bс $\alpha \beta$ & $0.73 \pm 0.09 \mathrm{ab} \alpha$ & $1.66 \pm 0.18$ e $\beta$ \\
\hline & & 2015 & $53.55 \pm 2.00 \mathrm{~b} \alpha \beta$ & $122.58 \pm 1.10 \mathrm{~b} \beta$ & $49.84 \pm 4.28$ a $\alpha$ & $0.62 \pm 0.04$ bc $\alpha \beta$ & $2.19 \pm 0.15 \mathrm{ab} \alpha$ \\
\hline & & 2016 & $56.67 \pm 1.07 \mathrm{~b} \alpha$ & $108.12 \pm 8.22 \mathrm{c} \gamma$ & $42.62 \pm 2.66 \mathrm{c} \beta$ & $0.53 \pm 0.10 \mathrm{c} \beta$ & $1.95 \pm 0.07 \mathrm{~cd} \alpha$ \\
\hline & \multirow{3}{*}{$\begin{array}{l}\text { 'Negru } \\
\text { Aromat' }\end{array}$} & 2014 & $62.49 \pm 0.86$ a $\alpha$ & $117.49 \pm 5.63 \mathrm{~b} \alpha \beta$ & $40.20 \pm 1.96$ с $\beta$ & $0.75 \pm 0.11$ a $\alpha$ & $2.35 \pm 0.11$ a $\alpha$ \\
\hline & & 2015 & $55.31 \pm 2.32 \mathrm{~b} \beta$ & $119.75 \pm 2.52 \mathrm{~b} \alpha$ & $53.49 \pm 5.04$ a $\alpha$ & $0.71 \pm 0.03 \mathrm{ab} \alpha$ & $2.35 \pm 0.17$ a $\alpha$ \\
\hline & & 2016 & $54.28 \pm 4.58 \mathrm{~b} \beta$ & $108.42 \pm 6.35$ с $\beta$ & $41.42 \pm 0.87$ с $\beta$ & $0.61 \pm 0.06$ bc $\alpha$ & $1.78 \pm 0.07$ de $\beta$ \\
\hline & \multirow{3}{*}{$\begin{array}{l}\text { 'Burgund } \\
\text { Mare' }\end{array}$} & 2014 & $64.81 \pm 3.36$ a $\alpha$ & $102.85 \pm 4.85 \mathrm{c} \beta$ & $52.29 \pm 3.00$ a $\alpha$ & $0.50 \pm 0.02 \mathrm{c} \beta$ & $1.74 \pm 0.07 \mathrm{de} \beta$ \\
\hline & & 2015 & $52.55 \pm 2.32 \mathrm{~b} \beta$ & $118.49 \pm 3.33 \mathrm{~b} \alpha$ & $48.90 \pm 2.01 \mathrm{ab} \alpha$ & $0.63 \pm 0.07$ abc $\alpha$ & $2.08 \pm 0.16$ bc $\alpha$ \\
\hline & & 2016 & $56.66 \pm 4.16 \mathrm{~b} \beta$ & $101.44 \pm 1.92$ с $\beta$ & $40.76 \pm 1.42$ с $\beta$ & $0.60 \pm 0.06$ bc $\alpha \beta$ & $1.85 \pm 0.02$ de $\beta$ \\
\hline \multicolumn{3}{|c|}{ Average } & $58.38 \pm 2.67$ & $113.04 \pm 4.55$ & $45.33 \pm 2.21$ & $0.64 \pm 0.05$ & $1.96 \pm 0.11$ \\
\hline \multicolumn{3}{|c|}{ Minimum Values } & $51.36 \pm 2.26$ & $101.44 \pm 1.92$ & $40.20 \pm 1.96$ & $0.50 \pm 0.02$ & $1.66 \pm 0.18$ \\
\hline \multicolumn{3}{|c|}{ Maximum Values } & $64.81 \pm 3.36$ & $132.61 \pm 2.43$ & $53.49 \pm 5.04$ & $0.75 \pm 0.11$ & $2.35 \pm 0.17$ \\
\hline \multicolumn{3}{|c|}{$\mathrm{F}}$. & 7.009 & 14.625 & 10.065 & 4.602 & 13.754 \\
\hline \multicolumn{3}{|c|}{ Sig. } & $* * *$ & $* * *$ & $* * *$ & $* *$ & $* * *$ \\
\hline \multirow{2}{*}{\multicolumn{2}{|c|}{ Variety }} & $\mathrm{F}$. & 5.169 & 19.421 & 1.560 & 6.207 & 12.659 \\
\hline & & Sig. & $* *$ & $* * *$ & $n s$ & $* * *$ & $* * *$ \\
\hline \multirow{2}{*}{\multicolumn{2}{|c|}{ Years }} & $\mathrm{F}$. & 8.808 & 24.450 & 23.634 & 3.561 & 20.823 \\
\hline & & Sig. & $* *$ & $* * *$ & $* * *$ & $n s$ & $* * *$ \\
\hline \multirow{2}{*}{\multicolumn{2}{|c|}{ Variety x Years }} & $\mathrm{F}$. & 7.029 & 7.315 & 7.533 & 4.320 & 10.768 \\
\hline & & Sig. & $* *$ & $* *$ & $* *$ & * & $* * *$ \\
\hline \multirow{2}{*}{\multicolumn{3}{|c|}{$\begin{array}{l}\text { Avram et al., } 2014 \\
\text { Galgano et al., } 2008\end{array}$}} & 63.72 & 113.24 & 31.30 & & \\
\hline & & & $83.17 \pm 13.91$ & $102.35 \pm 15.59$ & $20.97 \pm 10.16$ & $0.15 \pm 0.06$ & $3.91 \pm 1.16$ \\
\hline \multicolumn{3}{|c|}{ Đurđić et al., 2017} & 83.10 & 94.90 & 8.48 & 0.13 & 1.32 \\
\hline
\end{tabular}

Average value \pm standard deviation ( $\mathrm{n}=3$ ). Roman letters represent the significance of the variety difference $(p \leq 0.05)$. Greek letters represent the significance of the same variety cultivated in other year's difference $(p \leq 0.05)$. The difference between any two values, followed by at least one common letter, is insignificant. M.P.L. = Maximum Permissible Limit.

The results obtained are compared with those obtained by Paneque et al., 2017 (400.00 $\mu \mathrm{g} / \mathrm{L} \mathrm{Ni}$

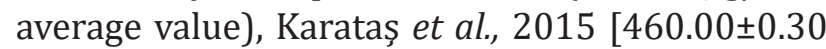
$\mu \mathrm{g} / \mathrm{L} \mathrm{Ni}$ (2011) Cabernet Sauvignon] and in the case of the results obtained by Thiel et al., 2004 (24.9 $\mu \mathrm{g} / \mathrm{L} \mathrm{Ni}$ average value), Geana et al., 2014 (18.39 $\mu \mathrm{g} / \mathrm{L}$ Ni Dragasani vineyard) these results are significantly lower than those obtained in this research (Tab. 4).

Concentration of $\mathrm{Zn}$ from wines varied in the range of $2134.29 \pm 6.32 \mu \mathrm{g} / \mathrm{L}$ to $3254.83 \pm 4.89$ $\mu \mathrm{g} / \mathrm{L}$ with an average of $2612.22 \pm 8.41 \mu \mathrm{g} / \mathrm{L} \mathrm{Zn}$, compared with $U$ concentration $0.13 \pm 0.01 \mu \mathrm{g} / \mathrm{L}$ to $0.31 \pm 0.04 \mu \mathrm{g} / \mathrm{L}$ with an average of $0.19 \pm 0.02$ $\mu \mathrm{g} / \mathrm{L}$. As the accumulation of these two metals is similar, lowest concentration was recorded in the 'Băbească Neagră' variety $[0.13 \pm 0.01 \mu \mathrm{g} / \mathrm{L} \mathrm{U}$
(2016)], [2134.29 $\pm 6.32 \mu \mathrm{g} / \mathrm{L} \mathrm{Zn}$ (2015)], while 'Burgund Mare' variety recorded the highest concentration $\quad[0.31 \pm 0.04 \quad \mu \mathrm{g} / \mathrm{L} \quad \mathrm{U}$ (2014)], [3254.83 $\pm 4.89 \mu \mathrm{g} / \mathrm{L} \mathrm{Zn} \mathrm{(2014)].} \mathrm{The} \mathrm{results}$ obtained are compared with those obtained by Geana et al., 2014 [0.86 $\mu \mathrm{g} / \mathrm{L} \mathrm{U}$ and 563.08 $\mu \mathrm{g} / \mathrm{L} \mathrm{Zn}$ (average value) Dragasani vineyard], Paneque et al., 2017 (2800 $\mu \mathrm{g} / \mathrm{L} \mathrm{Ni}$ average value). Concernig the results presented by Karataş et al., 2015 [5070.00 $\pm 850.00 \mu \mathrm{g} / \mathrm{L}$ Zn Syrah (2011), $4490.00 \pm 13.00 \mu \mathrm{g} / \mathrm{L}$ Zn Tannat (2011)] and also by Thiel et al., 2004 ( $0.55 \mu \mathrm{g} / \mathrm{L} \mathrm{U}$ average value), these results are significantly higher than those obtained in this research (Tab. 4).

Regarding $\mathrm{Hg}$ and $\mathrm{Pb}$ concentration from wines, this varied in the range of $0.19 \pm 0.02 \mu \mathrm{g} / \mathrm{L}$ to $0.43 \pm 0.04 \mu \mathrm{g} / \mathrm{L} \mathrm{Hg}, 21.28 \pm 1.52 \mu \mathrm{g} / \mathrm{L}$ to $55.10 \pm 3.49$ 


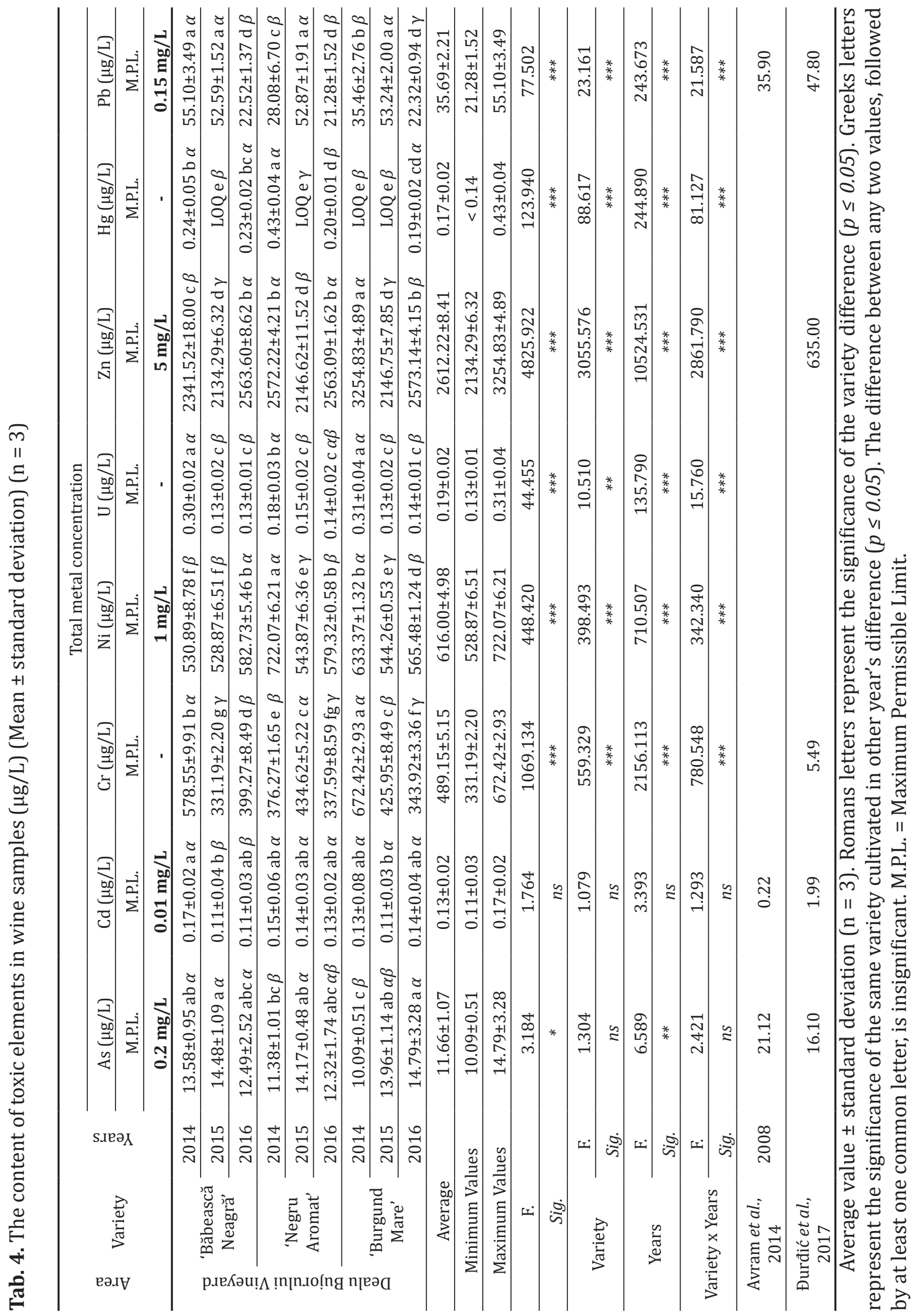


Tab. 5. Pearson correlation matrix between the main analysed wine parameters

\begin{tabular}{|c|c|c|c|c|c|c|c|c|c|c|}
\hline & $\mathrm{Ca}$ & $\mathrm{Mg}$ & $\mathrm{Na}$ & As & $\mathrm{Cr}$ & $\mathrm{Ni}$ & $\mathrm{U}$ & $\mathrm{Zn}$ & $\mathrm{Hg}$ & $\mathrm{Pb}$ \\
\hline $\mathrm{Ca}$ & 1.000 & & & & & & & & & \\
\hline $\mathrm{Mg}$ & $-0.438^{* *}$ & 1.000 & & & & & & & & \\
\hline $\mathrm{Na}$ & 0.075 & 0.129 & 1.000 & & & & & & & \\
\hline As & $-0.497^{* *}$ & 0.190 & 0.128 & 1.000 & & & & & & \\
\hline $\mathrm{Cr}$ & 0.288 & 0.077 & 0.418* & $-0.418^{*}$ & 1.000 & & & & & \\
\hline $\mathrm{Ni}$ & $0.728^{* *}$ & -0.306 & -0.312 & $-0.568 * *$ & 0.071 & 1.000 & & & & \\
\hline $\mathrm{U}$ & 0.325 & 0.133 & 0.202 & $-0.401^{*}$ & $0.899 * *$ & 0.196 & 1.000 & & & \\
\hline $\mathrm{Zn}$ & $0.708^{* *}$ & $-0.630^{* *}$ & -0.088 & $-0.629 * *$ & $0.538^{* *}$ & $0.579 * *$ & $0.553^{*}$ & 1.000 & & \\
\hline $\mathrm{Hg}$ & 0.170 & 0.023 & $-0.785^{* *}$ & -0.223 & -0.224 & $0.592^{* *}$ & 0.035 & 0.144 & 1.000 & \\
\hline $\mathrm{Pb}$ & $-0.401^{*}$ & $0.708^{* *}$ & $0.616^{* *}$ & 0.333 & 0.304 & $-0.528^{* *}$ & 0.233 & $-0.565^{* *}$ & $-0.534^{* *}$ & 1.000 \\
\hline
\end{tabular}

$\mu \mathrm{g} / \mathrm{L} \mathrm{Pb}$ with an average of $0.17 \pm 0.02 \mu \mathrm{g} / \mathrm{L} \mathrm{Hg}$ and $35.69 \pm 2.21 \mu \mathrm{g} / \mathrm{L} \mathrm{Pb}$. In the case of $\mathrm{Hg}$, the higest concentration were recorded at 'Cabernet Sauvignon' variety [0.43 $\pm 0.04 \mu \mathrm{g} / \mathrm{L} \mathrm{Hg}$ (2014)] and the lowest concentration were recorded at Burgund Mare' variety $[0.19 \pm 0.02 \mu \mathrm{g} / \mathrm{L} \mathrm{Hg}$ (2016)]. Pb recorded the lowest concentration at 'Cabernet Sauvignon' variety $[21.28 \pm 1.52 \mu \mathrm{g} / \mathrm{L}$ $\mathrm{Pb}$ (2016)], and the higest concentration were recorded at Băbească Neagră' variety $[55.10 \pm 3.49$ $\mu \mathrm{g} / \mathrm{L} \mathrm{Pb}(2014)]$. The results obtained are lower then obtained by Voica et al., 2009 [0.64 \pm 0.00 $\mu \mathrm{g} / \mathrm{L} \mathrm{Hg}, 21.74 \pm 0.00 \mu \mathrm{g} / \mathrm{L} \mathrm{Pb}]$, Paneque et al.,

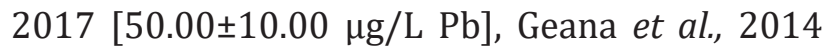
$(0.86 \pm 0.55 \mu \mathrm{g} / \mathrm{L} \mathrm{U})$.

Concentration of As $(0.2 \mathrm{mg} / \mathrm{L}), \mathrm{Cd}(0.01$ $\mathrm{mg} / \mathrm{L})$, Ni (1 mg/L), Zn (5 mg/L), and $\mathrm{Pb}(0.15$ $\mathrm{mg} / \mathrm{L}$ ) metals in analysed wine samples were under Maximum Permissible Limits (MPL), respectively as published by the Organization of Vine and Wine (OIV 2016).

The results indicated that Romanian wines are rich in $\mathrm{Ca}, \mathrm{Mg}, \mathrm{Cr}$ there are moderately rich in $\mathrm{Na}, \mathrm{Fe}, \mathrm{Ni}, \mathrm{Cu}$ and shows a low concentration of As, $\mathrm{Cd}, \mathrm{U}, \mathrm{Zn}, \mathrm{Hg}$ and $\mathrm{Pb}$.

The Pearson correlation between the elements analysed in wine

In order to determine if the concentration of metals can influence each other, the Pearson correlation coefficient was calculated for each studied parameter as it shown in (Tab. 5). A Pearson correlation coefficient value higher than 0.5 shows a strong correlation between the analysed varieties, a positive correlation between the two parameters shows that both parameters increased, a negative correlation indicates that a parameter increased while the second one decreased and vice-versa.

These provide a large number of both positive and negative correlations between the concentration of elements from wines. There are some relevant examples: $\mathrm{Mg} \& \mathrm{Ca}, \mathrm{As} \& \mathrm{Ca}, \mathrm{Cr} \&$ $\mathrm{Na}, \mathrm{Cr} \&$ As, Ni \& Ca, Ni \& As, U \& As, U \& Cr, Zn \& $\mathrm{Ca}, \mathrm{Zn} \& \mathrm{Mg}$, Zn \& As, Zn \& Cr, Zn \& Ni, Hg \& Na, Hg $\& \mathrm{Ni}, \mathrm{Pb} \& \mathrm{Ca}, \mathrm{Pb} \& \mathrm{Mg}, \mathrm{Pb} \& \mathrm{Na}, \mathrm{Pb} \& \mathrm{Ni}, \mathrm{Pb} \& \mathrm{Zn}$, $\mathrm{Pb} \& \mathrm{Hg}$. In the case of $\mathrm{Cu}, \mathrm{Cd}$ and $\mathrm{Fe}$ the values of the Pearson correlation coefficient for these parameters displayed no correlations.

Based on the previous Pearson correlation index, through this present research have been shown that the concentration of some metals from wine can influence each other.

\section{CONCLUSION}

In this study the characterisation of Romanian wines according to their elemental composition was performed. Calcium and magnesium were the most abundant elements in all investigated red and white wines samples. Concentration of $\mathrm{Na}(1 \mathrm{mg} / \mathrm{L}), \mathrm{Cu}(1 \mathrm{mg} / \mathrm{L})$, As $(0.2 \mathrm{mg} / \mathrm{L}), \mathrm{Cd}$ $(0.01 \mathrm{mg} / \mathrm{L}), \mathrm{Zn}(5 \mathrm{mg} / \mathrm{L})$ and $\mathrm{Pb}(0.15 \mathrm{mg} / \mathrm{L})$ metals in analysed wine samples were under Maximum Permissible Limits (MPL), respectively as published by the Organization of Vine and Wine (OIV 2005). Based on the previous Pearson correlation index, through this present research have been shown that the concentration of some metals from wine can influence each other. 
Acknowledgments. This paper was published under the frame of the Romanian Ministry of Agriculture and Rural Development, project ADER no. 14.2.2. "Quantitative studies on assessment and monitoring contaminants, on the chain of viticulture and winemaking to minimize the amount of pesticides and heavy metals as principal pollutants"

\section{REFERENCES}

1. Angelova VR, Ivanov AS, Braikov DM (1999). Heavy metals $(\mathrm{Pb}, \mathrm{Cu}, \mathrm{Zn}$ and $\mathrm{Cd})$ in the system soil - grapevine grape. J Sci Food Agric 79: 713-721.

2. Avram V, Voica C, Hosu A, Cimpoiu C, Măruţoiu C (2014). ICP-MS characterization of some Romanian white wines by their mineral content. Rev Roum Chim 59(11-12): 1009-1019.

3. Álvarez M, Moreno JM, Jos AM, Cameán AM, GustavoGonzález A (2007). Study of element profile of MontillaMoriles "fino" wines using inductively coupled plasma atomic emission spectrometry methods. J Food Compos Anal. 20: 391-395.

4. Blesić M, Drmać M, Batinić K, Spaho N, Martić NS, Zele M (2017). Levels of selected metals in wines from different Herzegovinian viticultural localities. Croat J Food Sci Technol 9(1): 1-10.

5. Bora FD, Donici A, Oşlobanu A, Fiţiu A, Babeş A, Bunea CI (2016). Qualitative assessment of the white wine varieties grown in Dealu Bujorului vineyard, Romania. Not Bot Horti Agrobo 44(2): 593-602.

6. Boubals D (2001). Copper in the control of grapes in France. Vingnevini 28(5):45-47.

7. Catarino S, Madeira M, Monteiro F, Rocha F, CurveloGarcia AS, Bruno de Sousa R (2008). Effect of bentonite characteristics on the elemental composition of wine. J Agric Food Chem 56: 158-165.

8. Đurđić S, Pantelić M, Trifković J, Vukojević V, Natić M, Tešć Ž, Mutić J (2017). Elemental composition as a tool for assessment of type, seasonal variability, and geographical origin of wine and its contribution to daily element intake. RSC Advances 7: 3151-2162. doi: 10.1039/C6RA25105F.

9. Galgano F, Favati F, Caruso M, Scarpa T, Palma A (2008). Analysis of trace elements in southern Italian wines and their classification according to provenance. Food Sci Technol 41:1808-1815.

10. Geana EI, Marinesc A, Iordache AM, Sandru C, Ionete RE, Bala C (2014). Differentiation of Romanian eines on geographical origin an wine variety by elemental composition and phenolic components. Food Anal Methods 7(10): 2064-2074.

11. Hague T, Petroczi A, Andrews PLR, Barker J, Naughton DP (2008). Determination of metal ion content of beverages and estimation of target hazard quotients: a comparative study. Chem Centr J 2: 1-13. https://doi. org/10.1186/1752-153X-2-13.

12. Karataş D, Aydin F, Aydin I, Karataş H (2015). Elemental composition of red wines in Southeast Turkey. Czech J Food Sci 33(3): 228-236.

13. Kristl J, Veber M, Slekovec M (2003). The contents of $\mathrm{Cu}$, $\mathrm{Mn}, \mathrm{Zn}, \mathrm{Cd}, \mathrm{Cr}$ and $\mathrm{Pb}$ at different stages of the winemaking process. Acta Chim Slov 50: 123-136.

14. Marais AD, Blackhurs DM (2009). Do heavy metals counter the potential health benefits of wine? JEMDSA 14: 77-79. https://doi.org/10.1080/22201009.2009.10872197.

15. Paneque P, Alvarez-Sotomayor TM, Clavijo A, Gomez IA (2010). Metal content in southern Spin wines and their classification according to origin and ageing. Microchem J 94(2): 175-179.

16. dos Santos NM, do Nascimento CWA, de Souza Júnior VS (2017). Lead isotope distribution and enrichment factors in soil profiles around an abandoned $\mathrm{Pb}$-smelter plant. Int J Environ Sci Technol 1: 1-12.

17. OIV (2016). Maximum acceptable limits of various substances contained in wine. In: Compendium of international methods of analysis of wine and must analysis. Paris, France.

18. Thiel G, Geisler G, Blechschmidt I, Danzer K (2004). Determination of trace elements in wines and classification according to their provenance. Anal Bioanal Chem 378: 1630-1636.

19. Provenzano MR, Bilali HE, Simeone V, Baser N, Mondelli D, Cesari G (2010). Copper contents in grapes and wines from a Mediterranean organic vineyard. Food Chem 122:1338-1343. doi:10.1016/j.foodchem.2010.03.103.

20. Voica C, Deheleanu A, Pamula A (2009). Method validation for determination of heavy metals in wine and slightly alcoholic beverages by ICP-MS. J Phys: Conf Ser 182 012036, doi:10.1088/1742-6596/182/1/012036. 